\title{
PICTORIAL NARRATIVE AND THE JOURNEY OF CHANGE FOR MEN AT STOPPING VIOLENCE DUNEDIN
}

\author{
Inge Andrew
}

Communication design seeks to combine information and visual representations into a narrative which allows for the idea of change. A recent example of this is the Obama "Hope" poster designed by Shepard Fairey during the 2008 US presidential campaign. Fairey used constructivist propaganda techniques to create a portrait of the politician, but also to incorporate the idealist notions on which the Obama campaign was built.' Apart from the 201 I copyright infringement case with the Associated Press (and Fairey's counterattack), it could be argued that this, more than any other symbol, was responsible for the wave of Blue votes that ultimately led to Obama's victory. People needed hope. Anne Condit refers to the use of the word "hope" on the poster as "glittering generality" - an example of persuasive language which the Institute for Propaganda Analysis describes as "virtue" words which "seek to make us approve and accept without examining the evidence."' The red, white and blue image, with its subject looking to the future, irritated some, but it also captured the imagination of the world.

Communication design can also give a voice to social justice, allowing community-based and global issues to enter the current discourse. In the early twentieth century, Käthe Kollwitz used graphic expressionist art to explore the social injustice of war. The expressionists were generally keenly aware of social crises, especially during the years prior to the First World War. ${ }^{3}$ The poor and social outcasts were often the subjects of Kollwitz's works; the poster reproduced here carries the slogan, "Free our Prisoners! Join the People's Alliance for the Protection of German Civilian and War Prisoners," communicating a tenacious sense of human empathy (Figure I).

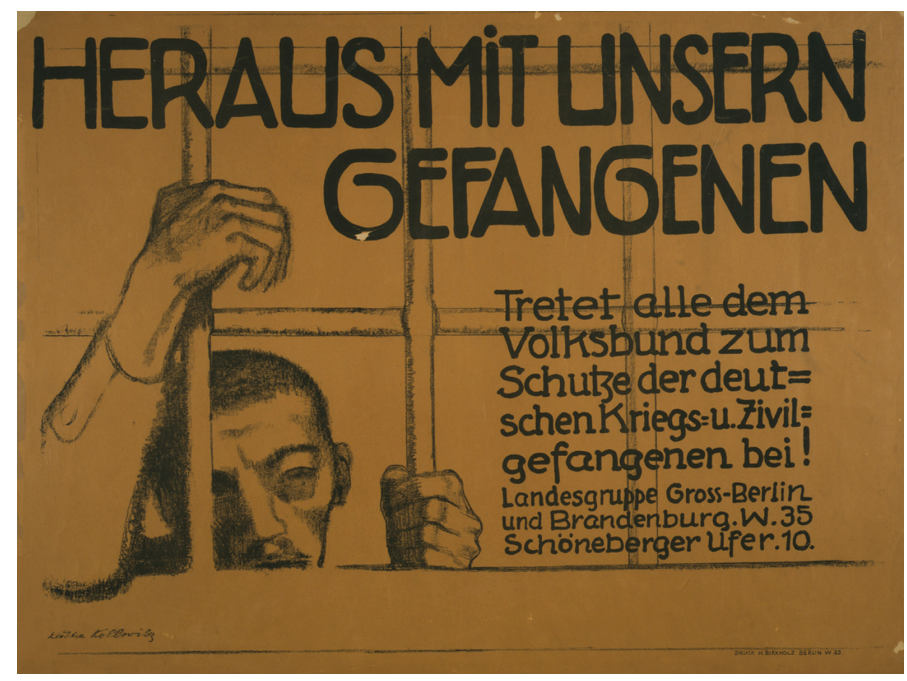

Figure I. Käthe Kollwitz, Free our Prisoners! Join the People's Alliance for the Protection of German Civilian and War Prisoners, 1919, lithograph, colour, 7I ×95 cm. ${ }^{4}$ 
In a contemporary example, Canadian domestic abuse charity Interval House set up a Broken Bride Registry stall at the 2018 Toronto Bridal Show, displaying artefacts such as Cigarette-Burn Cream, Cried-All-Night Sunglasses, Jealous-Rage Bandages and a Don't-Talk-Back Arm Sling. Each item displayed a barcode which transported the viewer to a real-life story of the reality of marriage for some women. The barcode scanner deliberately mimicked one that might be found at a bridal registry, a strategy which not only raised awareness but also prompted viewers to donate or add Interval House to their own wedding registry.

Over the last two years of my Masters project, I have been working with a group of people who don't generally have a voice in everyday discourse - perpetrators of domestic violence. I chose to work with a local agency, Stopping Violence Dunedin (SVD), who instead of placing blame on their clients, work to empower them with a sense of community and positive self-worth. These men, who are often victims of abuse themselves, are taught to appreciate and build on their own sense of worth.

Domestic violence is a complex issue and, by its very nature, is challenging to address. Aotearoa has one of the highest rates of reported violence towards women in the developed world. The wider community can have a skewed view of violent perpetrators, many believing that they should be locked up forever. While victims of domestic violence should absolutely continue to have a voice and a means to tell their stories, a punitive approach to perpetrators is problematic. Violence continues to dominate the national landscape and incarceration of violent perpetrators persists. Placing these men in the general prison system also assumes that they are a homogenous group.

The theory of intersectionality - which is usually used to refer to discrimination that women from different groups face - can also be used for men who choose to make a positive change in their lives. For civil rights activist Kimberlé Crenshaw, intersectionality can be seen as a traffic metaphor - cars at an intersection can come from different directions and cause a multitude of problems when they collide. If a black woman is harmed at the intersection, her injury could result from a multitude of discriminatory factors including race, gender, class, sexuality and ethnicity. ${ }^{6}$ In other words, when considering people and their place in society, oppression and culpability can't be understood through a single lens.

Perpetrators of domestic violence may experience intersectional discrimination, especially if they seek better options for themselves. This discrimination may reside in societal views and people's unwillingness to see past their violence. MacDowell ${ }^{\top}$ has discussed using an intersectional framework for addressing domestic violence, extending the application of intersectionality to encompass the identities of both victims and perpetrators. She recognised that perpetrators (who she refers to as "perceivable perpetrators") are often shaped by stereotypes of race, gender, class, sexuality and ethnicity. SVD challenges these embedded societal notions that violent perpetrators are a homogenous group and are not redeemable by offering individual and group therapy, interventions which offer positive change. This process of change is often long and complicated and can involve consciousness-raising, relationship-building and the development of altruism. Many of the men who have become involved in SVD's programmes have achieved positive behavioural outcomes. ${ }^{8}$

It became clear to me early in this project that the men who attend SVD are given, often for the first time, an opportunity to tell their story. Manager Cinnamon Boreham told me that they ask new clients direct questions like, "What happened to you?", "How did you get to be this way?" and "Why do you use violence as a means to an end?" Boreham and the other SVD facilitators seek to build a community around these men, which in turn allows them to feel safe enough to tell their own stories. 
Roguski and Gregory ${ }^{9}$ gathered narratives of transformation from former violent perpetrators in Aotearoa to try to understand their motivation for change. They found that storytelling and listening to other stories (from men who had "been there, done that") was a vital component of change. One informant was quoted as saying, "My turning point was telling my story. That was a big eye-opener for me. Telling the class what I did."'10 As a research tool, narrative inquiry works to consider personal experience over time, incorporating the relationship between peoples' lives and their cultural context."

Although I wasn't party to any stories from the men at SVD, I gained an understanding of how important this practice is to the journey of change from conversations and SVD facilitator interview data, as well as from the facilitators' own research. Men are both heard and listen to other men's stories, which help to establish empathy and close, authentic relationships with each other. I took the narrative enquiry in this project a step further, as the thematic content analysis of the facilitator interview data I analysed revealed seven themes associated with men's efforts to make a positive change in their lives. These themes included the importance of storytelling, undertaking a journey of transformation and the positive influence of mentors - other men who have attended SVD for some time and encourage newer participants to believe that the programme works if you stick to it. This approach is corroborated by another quotation from Roguski and Gregory's interview data: "Only those who have walked in my shoes can understand where I have been."'2

With the identification of these themes, it became evident that the journey of change could be pictorialised in order to continue to contextualise the process. This "narrative mapping"13 was combined with the concept of the Hero's Journey. In her book Design is Storytelling, Ellen Lupton'4 examines Joseph Campbell's ubiquitous concept of the circular journey, where the hero gets a call to adventure, initially refuses the call but, with the help of a sidekick (or mentor), embarks on a journey of tests and rewards, and returns home with a hero's story. This pattern is not only found in books and films, but can also be utilised in design, ensuring that the user of a product has some prior experience, if not a hero's experience per se.

In this project, the so-called hero (the new SVD member) and his mentor travel the journey of transformation together, a quest where the hero attempts to change the trajectory of his life. A mentor can show the way, acknowledging that trials and errors will be frequent along the way, but affirming that ultimately transformation will occur if there is a commitment to the mahi. The idea of the mentor and the journey also prompted reflection and the production of drawings of the gear the protagonists might carry with them in a kind of metaphorical first-aid kit.

Such a kit might contain:

I. The same shoes as the hero ("I have walked in your shoes")

2. Thread to bind the hero and the sidekick together

3. A mirror for the hero to reflect on his life and mirror the behaviour of his mentor

4. Oxygen mask to control breathing in stressful situations

5. A book of stories (from the hero and the mentor)

6. A hope stick or crutch to help along the journey

7. A Kabbalah bracelet (a Jewish folk custom where a red thread bracelet is worn to ward off evil spirits).

Figures 2 and 3 show a number of drawings prompted by the notion of the first-aid kit. 


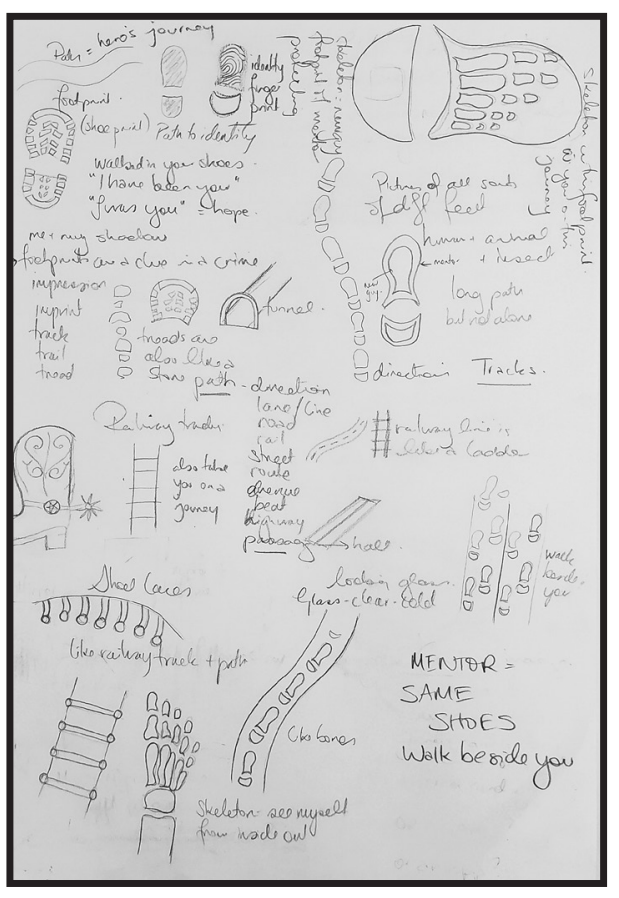

Figure 2. Inge Andrew, "I have walked in your shoes," 2020, workbook sketch. Photograph: Inge Andrew.

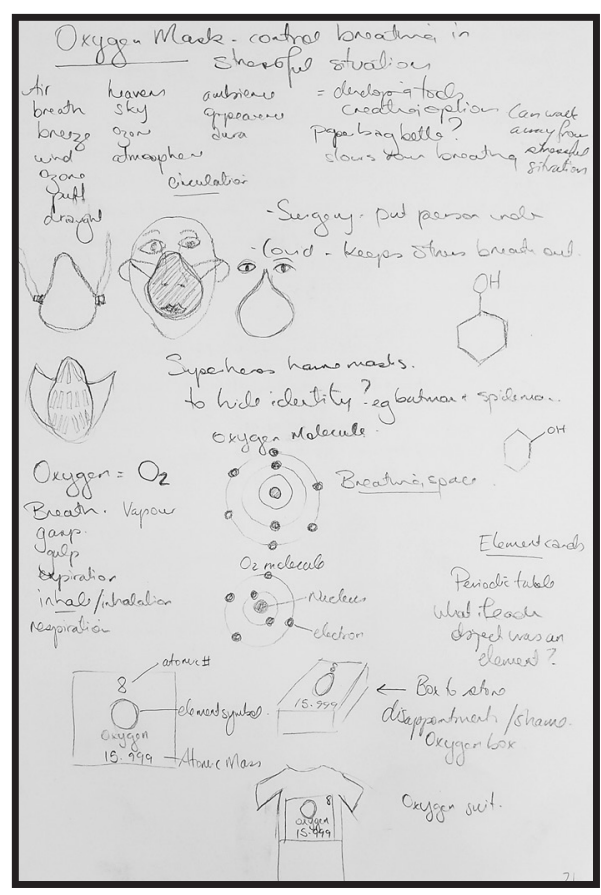

Figure 3. Inge Andrew, Oxygen mask, 2020, workbook sketch. Photograph: Inge Andrew.

This local interpretation of the hero's journey was further illustrated by combining the hero's journey with the first-aid kit drawings. As applied to to customer mapping, Kaplin ${ }^{15}$ refers to this as "narrative visualisation," where the map is a tool designed to share research findings and reveal critical moments as well as possible pain points. In my project, this concept helped to connect the ubiquitous notion of the hero's journey with the specific case of the men at SVD. They must go through a series of experiences, growth and changes to support their ongoing transition to a nonviolent lifestyle. Figure 4 (taken from my workbook) essentially offers a designed "pathway of support" for men as conceived by an outsider contemplating their journey of change.

Figure 4. Inge Andrew,

"Pathway of Support" for the socalled SVD hero and his mentor, 2020, workbook sketch. Photograph: Inge Andrew.

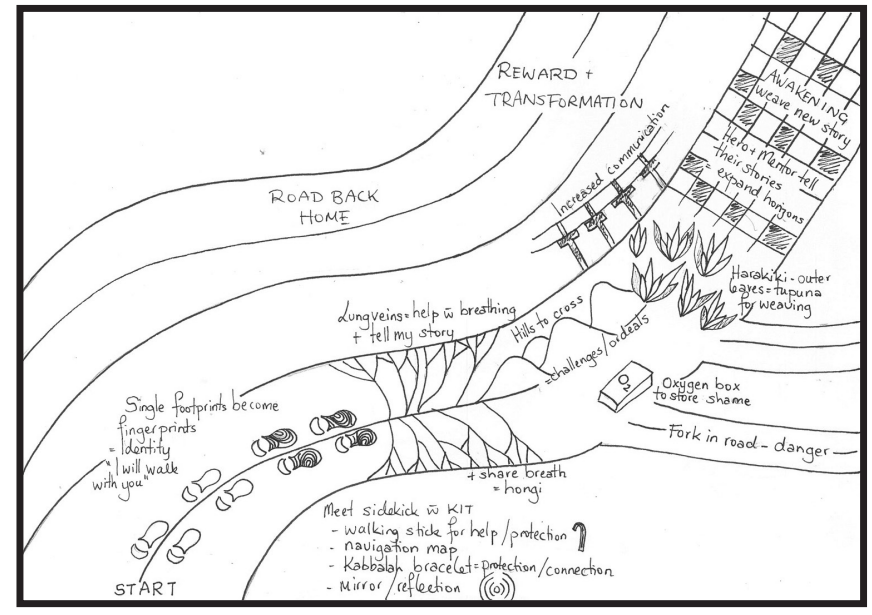


One of the key themes that arose from the research and facilitator interviews was the notion of cultural connectiveness and its role in the healing process. When interviewed, the SVD facilitators spoke about the importance of connecting with culture, whether it be Māori, Pasifika, or any other place where we feel connected through kinship (tūrangawaewae).

At some point in this metaphorical pilgrimage, the hero and his mentor pass through harakeke (flax) groves, which are eventually woven into new stories. Harakeke is an important element in this journey, as it can be used to represent whānau - the outer leaves are awhi rito (parents) and tūpuna (grandparents), and the inner leaves represent the rito (child). Only the outer tūpuna leaves are cut for use, so not to weaken the whole plant.16 The mentor stands in the role of awhi rito and, together with the hero (rito), they cut the outer leaves of the harakeke to weave a new story of change. Raranga (weaving) can also embody connection as well as knowledge and stories in Te Ao Māori. ${ }^{17}$

In further reflection on the journey (see Figure 4), the metaphors associated with it as well as the themes of hope and transformation, I identified seven milestones for the participants, which were approved by the SVD facilitators who were part of a focus group. These milestones are:

I. Enter the door of SVD

2. Return to SVD

3. Tell your story

4. Make connections with peers

5. See your story from other perspectives (increasing consciousness of your own actions)

6. Take threads of other stories that apply to you

7. Accept hope/transformation.

The first two milestones, entering and returning to SVD, were important to recognise, as participants are often triggered by events at group sessions that result in them failing to return. One focus group member said he knew he needed to be there, and returned the next week. A second focus group member said it took years for him to return to SVD after his initial visit. Milestones also form an important element of the journey-mapping process in design, where a series of actions drives the client on a particular journey. According to Lupton, "Action drives stories and it also drives the design process." 18 She means that good design can build an unfolding story which works to create connections, images and memories for the user. Storytelling from different perspectives continues to be a strong focus in this project, both in terms my own investigations and the stories that the men form together at SVD.

My Masters' project investigated whether communication design can support the transformation of violent male offenders within Stopping Violence Dunedin. I used applied design methodologies, critical thinking and sketching, as well as reflection, to understand the journey of change towards nonviolence for men at SVD. I was able to add to the value process by creating themes, milestones and a pictorial narrative. Storytelling, cultural connectivity and whakawhanaungatanga (relationship building) were key components of this project, which followed a natural progression to a narrative inquiry, seeking to understand people within their own cultural and societal contexts. The resulting pictorial narrative map launched my own journey towards developing a design outcome aimed at contextualising the journey of change in order to walk alongside men who are changing the trajectory of their lives for the better. 
Inge Andrew (ORCID ID: https://orcid.org/0000-0002-5308-9577) graduated with a Graduate Diploma in Design (Communication) with Distinction and is currently completing a Masters of Design at Otago Polytechnic. She is also working as a lecturer at the School of Design.

I Anne Condit, "Hope: Propaganda and the Portrait of a President," Compass:A Journal of Leadership and Service at BirminghamSouthern College, 12 (Spring 2010), 16-19, at 17, www.bsc.edu/academics//krulak/hess/compass/compass/compass\%20 $2010 \% 20$ edition.pdf\#page $=18$

2 Ibid

3 Philip Meggs and Alston Purvis, Megg's History of Graphic Design (New York: John Wiley \& Sons, 2008).

4 https://commons.wikimedia.org/wiki/File:Heraus_mit_unsern_Gefangenen!_Tretet_alle_dem_Volksbund_zum_Schutze_der_ deutschen_Kriegs-_u._Zivilgefangenen_bei!_LCCN2004665995.jpg (accessed I0 May 2021).

5 Cass Nager, "The Broken Bride Registry: Not Every Bride Lives Happily Ever After," Interval House, 22 May 20 I9, http://www. intervalhouse.ca/blog/the-broken-bride-registry-not-every-bride-lives-happily-ever-after/.

6 Patrick R Grzanka, Intersectionality: A Foundations and Frontiers Reader (Boulder, CO:Westview Press, 20 I4).

7 Elizabeth MacDowell, "Theorizing from Particularity: Perpetrators and Intersectional Theory on Domestic Violence," The Journal of Gender, Race and Justice, 16:2 (2013), 531-76.

8 Sean Manning, Tanya-Maree Felton, Cinnamon Boreham and Jacob Ashdown, "Increasing the Effectiveness of Stopping Violence Dunedin Programmes" (Unpub. preliminary report for the Lottery Grants Board, July 20 I7).

9 Michael Roguski and Natalie Gregory, Former Family Violence Perpetrators' Narratives of Change: Prepared for the Glenn Inquiry (Wellington: Kaitiaki Research and Evaluation, 2014), https://ndhadeliver.natlib.govt.nz/delivery/DeliveryManagerServlet?dps_ pid=|E25596493\&dps_custom_att_I =ilsdb.

10 Ibid., 34.

II Kim Ethrington, "Narrative Approaches to Case Studies" (PowerPoint presentation, Keele University, Staffordshire, UK), $\quad$ https://www.keele.ac.uk/media/keeleuniversity/facnatsci/schpsych/documents/counselling/conference/5thannual/ NarrativeApproachestoCaseStudies.pdf.

12 Ibid, 4l.

13 Jennifer Lapum et al., "Pictorial Narrative Mapping as a Qualitative Analytic Technique," International Journal of Qualitative Method, I4:5 (2015), I- I5.

14 Ellen Lupton, Design is Storytelling (New York: Cooper Hewitt, Smithsonian Design Museum, 2017).

15 Kate Kaplin, "The 5 Steps of Successful Customer Journey Mapping," Nielsen Norman Group, 28 May 2017, https://www. nngroup.com/articles/customer-journey-mapping-process/.

16 Nancy Swarbrick, "Flax and Flax Working," Te Ara - The Encyclopedia of New Zealand, https://teara.govt.nz/en/flax-and-flaxworking/print.

17 Gloria Taituha, "He Kākahu, He Korowai, He Kaitaka, He Aha Atu Anō?The Significance of the Transmission of Māori Knowledge Relating to Raranga and Whatu Muka in the Survival of Korowai in Ngāti Maniapoto in a Contemporary Context" (MA exegesis, Auckland University of Technology, 20 I4), https://openrepository.aut.ac.nz/bitstream/handle/ I 0292/8233/TaituhaG. pdf? sequence $=3$ \&isAllowed $=y$.

18 Ibid., 21. 